\title{
Studies on the Genetic Variations between Field Strains of Pectinophora gossypiella (SAUNDERS) using Polymerase Chain Reaction (PCR) Technique Mahmoud, M. A. ${ }^{1}$;. L. Ibrahim ${ }^{1}$; A. A. Khidr ${ }^{2}$ and M. S. Abd-EI Hameed ${ }^{2}$ \\ ${ }^{1}$ Plant Protection Department, Faculty of Agriculture, Al-Azhar University \\ ${ }^{2}$ Plant Protection Research Institute, Agricultural Research Center, Dokki, Giza
}

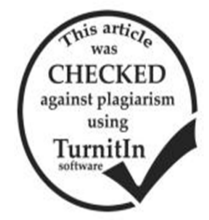

\section{ABSTRACT}

Five different strains of the pink bollworm, Pectinophora gossypiella (Saunders) were used in the present study.The laboratory strain was used as a baseline in the molecular biology assays. Four strains were selected from natural popoulations, fields located in Qalubia, Gharbia, Menoufia and Kafr-Elsheikh Governorates. The molecular studies included the analysis of the plod genomic DNA of the tested strains under this study by using Random Amplified Polymorphic DNA (RAPD) method. A battery of five primers was used to evaluate the mutagenic differentiation among the five strains. The primer S4 generated the highest numbers of fragments $(32$ fragments). Both primers K15 and S8 generated 23 fragments. The lowest number of fragments appeared in primer C15 and primer P8, (18 fragments). The molecular sizes of fragments ranged between 180 and 1182bp. The RAPD patterns resulted from amplification of DNA of the field colony strains and laboratory strain of the pink bollworm P. gossypiella revealed that the lowest value of similarity index $(0.0 \%)$, which reflects the highest degree of change in DNA structure and sequences between the genomes of laboratory pink bollworm and those exposed to a wide spread of different insecticides for controlling the pest in the fields. On the other hand, there is no compilitily similarity index between field strains and laboratory strain of pink bollworm. The highest similarity index between field strains and laboratory strain of the pink bollworm appeared in primer P8, while the lowest similarity index between field strains and laboratory strain of the pink bollworm appeared in primer K15. The primer S4 recorded that is no similarity index between Qalubia strain and each of laboratory and field strains. It is interrest to note that the less damaging effect to pink bollworm DNA could be attributed to a good detoxifying mechanism developed by the insect as a result of wide spread and long term exposure of insect larvae in additional to different thermal degrees in the fields.

\section{INTRODUCTION}

The pink bollworm, Pectinophora gossypiella (Saunds.) (Lepidoptera : Gelechiidae) is the key pest of cotton in Egypt, $75 \%$ of insecticides use on cotton is directed against this pest. It has been introduced into Egypt between 1903-1913 from India within badly ginned cotton seeds (willcooks, 1916). In 1913, this pest spread to such degree that it became a real danger to the cotton crop in Egypt. It is capable of causing tremendous financial losses of the cotton yield.

RAPD-PCR technique helps in genetic analysis of any new species without any prior knowledge about the particular DNA sequences or the genes of these new species. RAPD-PCR technique is not limited to a single locus but theoretically detects polymorphism across the whole genome, either coding or non coding regions in contradiction to biochemical markers which are limited to few genomic regions, so that this method may be used to any mutagen such as insecticides. Different parts of the genome can evolve at different rates (Nei, 1987). It is possible that the regions amplified by PCR evolve at higher rate. Thus RAPD-PCR finger prints can obtain a higher variability especially if the amplified regions contain micro or minisatellite DNA (Baruffi et al., 1993).

The objective of the present work is to investigate the use of Random Amplified Polymorphic DNA(RAPDPCR) technique to study genetic variation of field collected pink bollworm, P. gossypiella.

\section{MATERIALS AND METHODS}

\section{1-Pectinophora gossypiella, laboratory strain:}

Laboratory strain was brought from the Bollworm's Research Department, Plant Protection Research Institute, Dokki Giza, brought from cotton fields and maintained over ten years on artificial diet according to Abd El-Hafez et al., 1982).

\section{2-Pectinophora gossypiella, field strains:}

Four strains of pink bollworm $P$. gossypiella were colected from Qalubia, Gharbia, Menoufia and KafrElsheikh Governorates at the late season of 2016 exposed regularly to four treatments asssociated to the recommended insecticidal applications for controlling cotton pests according to routine schedule program set annually by the Central Administration for Pest Control, Ministry of Agriculture. These applications are chitin synthesis inhibitors plus organophosphates, pyrethroids, organophosphates and crbamates. These strains were collected at the end of season for molecular biology assay.

\section{3-Rearing technique:}

Rearing technique in this study was based on artificial diet of kideny bean according to Abd El-Hafez et $a l$., 1982). Ten pairs of freshly emerged moths were confined in glass chimney cage. Inside cage, a piece of cotton wool previously soaked in $10 \%$ sugar solution was suspended to be renewed every 48 hours for moths feeding. The top and bottom of each cage were covered with muslin clothes kept in position by rubber bands for females egg-laying. Eggs were deposited on muslin clothes. Cages were maintained at $27 \pm 1^{\circ} \mathrm{C}$ and 75 $\pm 5 \%$ R.H. and were examined daily for collecting muslin containing eggs. Eggs were placed in glass jars $(3.5 \mathrm{x}$ $12.5 \mathrm{~cm}$ ), covered with two layers of fine and soft paper kept in position by rubber bands and maintained at the same rearing conditions until hatching. The newly hatched larvae were used in the experiments.

\section{4-Molecular genetic}

\section{a. DNA extraction:}

Half gm of $P$. gossypiella larvae was homogenized in $1 \mathrm{ml}$ digestion buffer and $40 \mu$ proteinase $\mathrm{k}$ (freshy prepared) the incubated at $55{ }^{\circ} \mathrm{C}$ for $18 \mathrm{hr}$, then bulked DNA extraction was performed using DNA assay Mini kit (QLAGEN).

\section{b. Polymerase Chain Reaction (PCR):}

Genomic DNA was analyzed with RAPD-PCR technique according to the method described by Williams et al. (1990).

PCR amplification was performed using random 10 mer arbitrary primers synthesized by (Operon biotechnologies, Inc. Germany) Table (1) with the following sequences: 
Table 1. List of the primer names and their nucleotide sequences used in the study

\begin{tabular}{lcc}
\hline Number & Name & Sequence \\
\hline 1 & S 4 & GGACTGGAGT \\
2 & C15 & GACGGATCAG \\
3 & K15 & CTCCTGCCAA \\
4 & P8 & GGAGCCCAGT \\
5 & S8 & GTCCACACGG \\
\hline
\end{tabular}

Amplification was conducted in $25 \mu 1$ reaction volume containing the following reagents: $2.5 \mu \mathrm{l}$ of dNTPs (2.5Mm), $2.5 \mu 1 \mathrm{MgCl}_{2}(2.5 \mathrm{Mm})$, and $2.5 \mu \mathrm{l}$ of $10 \mathrm{x}$ buffer, $3.0 \mu \mathrm{l}$ of templat DNA $(25 \mathrm{ngl} / \mu \mathrm{l}), 1 \mu \mathrm{l}$ of Taq polmymerase $(1 \mathrm{U} / \mu \mathrm{l})$ and $10.5 \mu \mathrm{l}$ of sterile $\mathrm{dd} \mathrm{H}_{2} \mathrm{O}$. The DNA amplifications were performed in an automated thermal cycle (model Techno 512) programmed for one cycle at $94^{\circ} \mathrm{C}$ for $4 \mathrm{~min}$ followed by 45 cycles for $1 \mathrm{~min}$ at $94{ }^{\circ} \mathrm{C}$, and $1 \mathrm{~min}$ at $36^{\circ} \mathrm{C}$, and $2 \mathrm{~min}$ at $72{ }^{\circ} \mathrm{C}$. The reaction was finally stored at $72^{\circ} \mathrm{C}$ for $10 \mathrm{~min}$. Amplified products were size frarctioned (using ladder marker) by electrophoresis in 1.5\% agarose gels in TBE buffer at $120 \mathrm{~V}$ for $1 \mathrm{hr}$. The bands were visualized by ethidium bromide under UV florescent and photographed.

Similarity index:

The similarity index was used to compare patterns within as well as between populations. This index reflects the extent of band sharing and calculated as:

$$
2 \mathbf{N}_{\mathrm{ab}} /\left(\mathbf{N}_{\mathrm{a}}+\mathbf{N}_{\mathrm{b}}\right)
$$

Where $2 \mathrm{~N}_{\mathrm{ab}}$ is number of bands common to individuals $\mathbf{a}, \mathbf{b}$.

$N_{a}$ and $N_{b}$ are total number of bands in a and $b$, respectively.

\section{RESULTS AND DISCUSSION}

After PCR amplification, the number and size of fragments may differ between strains. The specific patterns of the DNA observed represent the genetic make-up of each strain. Identical sized bands observed between different strains indicate genetic relatedness or similarity. The $4^{\text {th }}$ instar larvae of the laboratory strain as well as field colony strains of the pink bollworm, Pectinophora gossypiella showed differences in RAPD-PCR patterns of amplified genomic DNA.

Random amplified polymorphic DNA polymerase chain reaction (RAPD-PCR) of five different strains of $P$. gossypiella collected from different Governorates:

Five primers of arbitrary sequences were used to screen pooled genomic DNA of the different five strains.

In the $4^{\text {th }}$ instar larvae of $P$. gossypiella, the finger prints generated by both $\mathrm{P} 8, \mathrm{C} 15$ and $\mathrm{S} 8$ revealed unique and monomorphic, profiles for the pest strains; whereas the fingerprints generated by K15 revealed polymorphic, unique and monomorphic for the pest strains in terms in number and position of RAPD fragments. Whereas the fingerprint generated by $\mathrm{S} 4$ revealed polymorphic and unique for the tested strains in terms in number and position of RAPD fragments. These primers gave good amplification with distinct fragments.

Primer S4 showed the largest number of RAPD fragments where 32 bands were produced in the five strains of the pest under the study. (Table 2 and Fig. 1). There were 5, 3, 10, 6 and 8 bands in the laboratory strain, Qalubia, Gharbia Menoufia, and Kafr-Elsheikh strains respectively. Two fragments of 1182 and $486 \mathrm{bp}$ were shared in Gharbia and Kafr-Elsheikh colony strains. Amplified fragments of 479, 350 and 315 bp were detected only in Qalubia field colony strain. Four 1166, 1000, 390 and 360 bp were appeared only in Menoufia field strain. Four fragments of 1006, 379, 348 and 319 bp were detected only in Kafr-Elsheikh colony field strain.

Amplified fragments of the laboratory strain as well as Qalubia Gharbia, Menoufia and Kafr-Elsheikh field colony strains were detected in the $4^{\text {th }}$ instar larvae homogenates. Two fragments of 524 and 227 were appeared only in the laboratory strain. Polymorphism generated by the primer S4 showed 5 polymorphic and 18 unique in the tissues of the $4^{\text {th }}$ instar larvae of the tested pest.

Table 2. Total numbe and size of RAPD-PCR fragments generated by arbitrary primers in different strains of P.gossypiella larvae using primer S4.

\begin{tabular}{|c|c|c|c|c|c|c|c|}
\hline MW-bp & Lab. & Qalubia & Gharbia & Menoufia & Kafr-Elsheikh & Frequency & Polymorphism \\
\hline Band1 & ----- & ---- & 1182 & --- & 1182 & 0.400 & Polymorphic \\
\hline Band2 & ----- & ----- & ---- & 1166 & --- & 0.200 & Unique \\
\hline Band3 & ----- & ----- & 1114 & ----- & ----- & 0.200 & Unique \\
\hline Band4 & ----- & ----- & ----- & ----- & 1006 & 0.200 & Unique \\
\hline Band5 & ----- & ----- & ----- & 1000 & ----- & 0.200 & Unique \\
\hline Band6 & ----- & ----- & 863 & ----- & ----- & 0.200 & Unique \\
\hline Band7 & ----- & ----- & 708 & ----- & ----- & 0.200 & Unique \\
\hline Band8 & 524 & ----- & ----- & ----- & ----- & 0.200 & Unique \\
\hline Band9 & ----- & ----- & 486 & ----- & 486 & 0.400 & Polymorphic \\
\hline Band10 & ----- & 479 & ----- & ----- & ----- & 0.200 & Unique \\
\hline Band11 & ----- & ---- & 417 & ----- & ----- & 0.200 & Unique \\
\hline Band12 & ----- & ----- & --- & 390 & ----- & 0.200 & Unique \\
\hline Band13 & ----- & ----- & ----- & ---- & 379 & 0.200 & Unique \\
\hline Band14 & ----- & ----- & ----- & 360 & ---- & 0.200 & Unique \\
\hline Band15 & 353 & ----- & 353 & ---- & ---- & 0.200 & Polymorphic \\
\hline Band16 & ----- & 350 & ---- & ----- & ----- & 0.200 & Unique \\
\hline Band17 & ----- & ----- & ----- & ----- & 348 & 0.200 & Unique \\
\hline Band18 & ----- & ----- & ----- & ----- & 319 & 0.200 & Unique \\
\hline Band19 & ----- & 315 & ----- & ----- & ----- & 0.200 & Unique \\
\hline Band20 & ----- & ----- & 243 & ----- & ----- & 0.200 & Unique \\
\hline Band21 & 227 & ----- & ----- & ----- & ----- & 0.200 & Unique \\
\hline Band22 & 201 & ----- & 201 & 201 & 201 & 0.800 & Polymorphic \\
\hline Band23 & 180 & ---- & 180 & 180 & 180 & 0.800 & Polymorphic \\
\hline
\end{tabular}




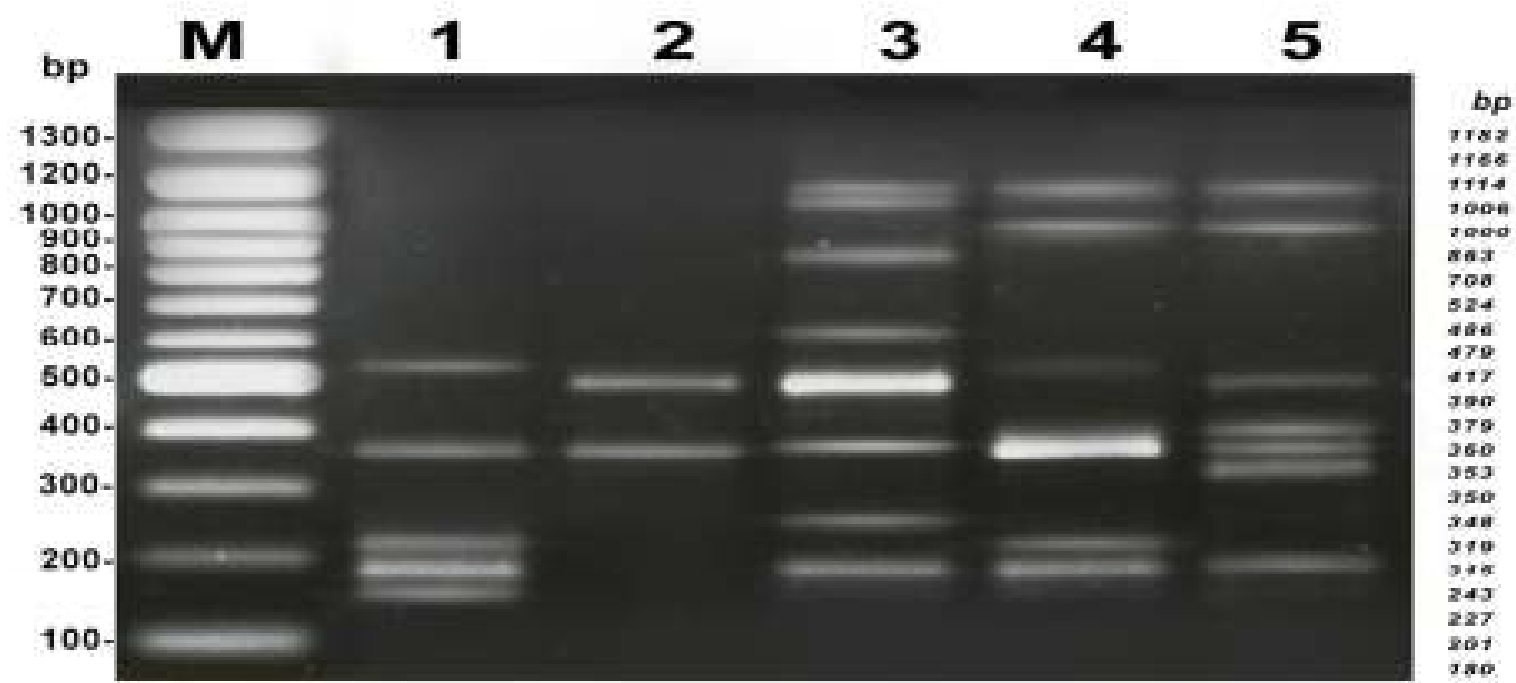

Fig. 1. RAPD-PCR produced for different strains of $P$. gossypilla larvae using primer S4. Where is lane $1=$ Lab, lane 2 = Qalubia, lane 3= Gharbia, lane 4= Menoufia and lane 5= Kafr-Elsheikh.

Analysis of the similarity index showed a major drop from 0.44 to 0.0 . In this respect highly resistance could be noticed in Qalubia field strain where the similarity index equal 0.0. (Table3).

Table 3. Estimated similarity index between five strains of $P$. gossypiella larvae using primer S4.

\begin{tabular}{|c|c|c|c|c|c|}
\hline Strains & Lab. & Qalubia & Gharbia & Menoufia & $\begin{array}{c}\text { Kafr- } \\
\text { Elsheikh }\end{array}$ \\
\hline Lab. & ----- & 0.0 & 0.40 & 0.36 & 0.30 \\
\hline Qalubia & ----- & ----- & 0.0 & 0.0 & 0.0 \\
\hline Gharbia & ----- & ----- & ----- & 0.25 & 0.44 \\
\hline Menoufia & ----- & ----- & ---- & ----- & 0.28 \\
\hline $\begin{array}{l}\text { Kafr- } \\
\text { Elsheikh }\end{array}$ & ----- & ----- & ----- & ----- & ----- \\
\hline
\end{tabular}

Using primer $\mathrm{C} 15$ revealed some variability between the five different strains of $P$. gossypiella.

The RAPD-PCR pattern produced by amplification of the $4^{\text {th }}$ instar larvae DNA with primer C15 contained a total of 18 bands (Table 4). The number of DNA fragments ranged from 3 to 4 bands.

The PCR patterns resulted from using Primer C15 discriminated between the laboratory and the four field colony strains. Three amplified fragments of 424, 331 and
$195 \mathrm{bp}$ in the laboratory strain were not detected in the field colony strains. Four fragments were noticed in each of laboratory strain as well as Gharbia and Kafr-Elsheikh field colony strains; whereas three fragments were occurred in both Qalubia and Menoufia field colony strains.

The fingerprints generated by primer $\mathrm{C} 15$ revealed thirteen unique $\&$ one polymorphic profiles.

The total number of amplified fragments generated by this primer was 18 bands. There were 4, 3, 4, 3 and 4 bands in the laboratory strain, Qalubia, Gharbia, Menoufia and Kafr-Elsheikh field colony strains; respectively (Table 4 and Fig. 2). Only one band of $242 \mathrm{pb}$ was shared in laboratory and the field colony strains. Another two bands of 424 and $331 \mathrm{pb}$ were found in the laboratory and did not appeared in the four field colony strains. Moreover, two bands of 401 and 327 bp were found only in Qalubia field colony strain. Another three fragments of 429, 371 and $312 \mathrm{bp}$ were detected only in Gharbia field strain and absent in the other four strains. Two fragments of 440 and 346 were noticed only in Menoufia field strain. The other three bands of 420, 354 and 305 bp were detected only in Kafr-Elsheikh field colony strain.

Table 4. Total numbe and size of RAPD-PCR fragments generated by arbitrary primers in different strains of $P$. gossypiella larvae using primer $\mathrm{C} 15$.

\begin{tabular}{lccccccc}
\hline MW-bp & Lab. & Qalubia & Gharbia & Menoufia & Kafr-Elsheikh & Frequency & Polymorphism \\
\hline Band1 & ----- & ----- & ----- & 440 & ---- & 0.200 & Unique \\
Band2 & ---- & ---- & 429 & ----- & ---- & 0.200 & Unique \\
Band3 & 424 & ----- & ---- & ---- & --- & 0.200 & Unique \\
Band4 & ----- & ---- & ---- & ---- & 420 & 0.200 & Unique \\
Band5 & ----- & 401 & ---- & ---- & ----- & 0.200 & Unique \\
Band6 & ----- & ----- & 371 & ---- & --- & 0.200 & Unique \\
Band7 & ----- & ----- & ----- & ---- & 354 & 0.200 & Unique \\
Band8 & ---- & ---- & ---- & 346 & ----- & 0.200 & Unique \\
Band9 & 331 & ---- & ---- & ---- & --- & 0.200 & Unique \\
Band10 & ----- & 327 & ---- & ---- & --- & 0.200 & Unique \\
Band11 & ----- & ----- & 312 & ---- & ---- & Unique \\
Band12 & ---- & ---- & ---- & --- & 305 & Unique \\
Band13 & 242 & 242 & 242 & 242 & 242 & 1.000 & Monomorphic \\
Band14 & 195 & ----- & ----- & ---- & ----- & 0.200 & Unique \\
\hline
\end{tabular}




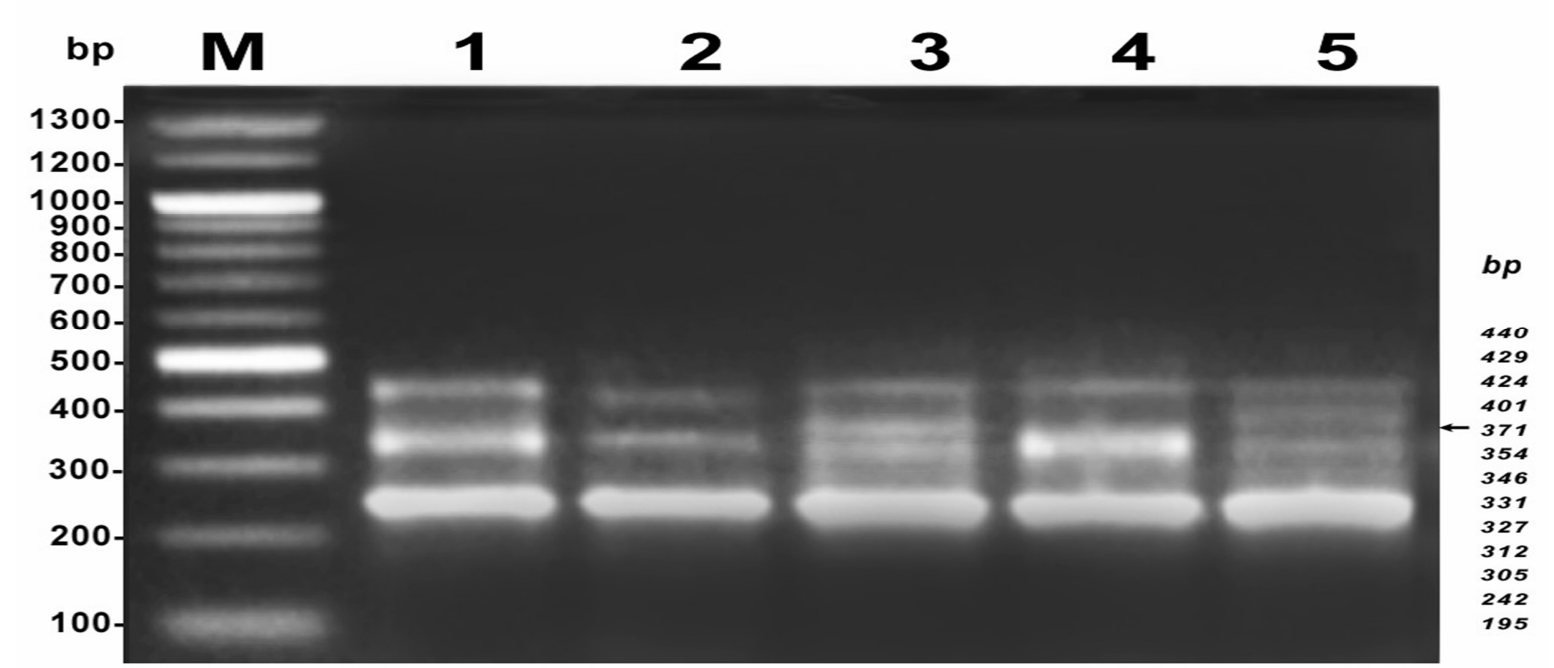

Fig. 2. RAPD-PCR produced for different strain of $P$. gossypilla larvae using primer $\mathbf{C} 15$. Where is lane $1=\mathrm{Lab}$, lane 2 = Qalubia, lane 3= Gharbia, lane 4= Menoufia and lane 5= Kafr-Elsheikh.

As illustrated in (Table 5), the values of similarity index generated by the primer $\mathrm{C} 15$ ranged from 0.25 to 0.28 relative to the baseline laboratory strain, indicating highly resistance in the fourth instar larvae of the pest.

Table 5. Estimated similarity index between five strains of $P$. gossypiella larvae using primer C15.

\begin{tabular}{|c|c|c|c|c|c|}
\hline Strains & Lab. & Qalubia & Gharbia & Menoufia & $\begin{array}{c}\text { Kafr- } \\
\text { Elsheikh }\end{array}$ \\
\hline Lab. & ----- & 0.28 & 0.25 & 0.28 & 0.25 \\
\hline Qalubia & ----- & ----- & 0.28 & 0.33 & 0.28 \\
\hline Gharbia & ---- & ----- & ----- & 0.28 & 0.25 \\
\hline Menoufia & ----- & ----- & ----- & ----- & 0.28 \\
\hline $\begin{array}{l}\text { Kafr- } \\
\text { Elsheikh }\end{array}$ & ----- & ----- & ----- & ----- & ----- \\
\hline
\end{tabular}

Primer K15 showed 23 fragments detected in the five strains of pink bollworm $P$. gossypiella larvae (Table 6 and Fig.3). There were 5, 4, 6, 4 and 4 bands in the laboratory, Qalubia, Gharbia Menoufia and Kafr-Elsheikh strains; respectively.

Fragment of 211 bp was detected in the all strains; the four fragments of 529,396, 324 and 270 bp were appeared only in the baseline laboratory strain. The fragment of 635bp was detected only in Qalubia and Gharbia field colony strains; whereas the two fragments of 294 and 255 bp were found only in Qalubia field colony strain of the pest. On the other hand, the fragment of 476 bp was detected in both Gharbia and Kafr-Elsheikh field colony strains. The fragments of 424, 315 and $260 \mathrm{bp}$ were detected only in Gharbia field colony strain. The three fragments of 467, 364 and 243 bp were appeared only in Menoufia field colony strain; whereas the two fragments of 330 and 232 bp were found only in Kafr-Elsheikh field colony strains.

Table 6. Total numbe and size of RAPD-PCR fragments generated by arbitrary primers in different strains of $P$. gossypiella larvae using primer K15.

\begin{tabular}{lccccccc}
\hline MW-bp & Lab. & Qalubia & Gharbia & Menoufia & Kafr-Elsheikh & Frequency & Polymorphism \\
\hline Band1 & ----- & 635 & 635 & ----- & ---- & 0.400 & Polymorphic \\
Band2 & 529 & ----- & ---- & ---- & ---- & 0.200 & Unique \\
Band3 & ----- & ---- & 476 & ---- & 476 & 0.400 & Polymorphic \\
Band4 & ----- & ----- & ---- & 467 & ---- & 0.200 & Unique \\
Band5 & ----- & ----- & 424 & ----- & ---- & 0.200 & Unique \\
Band6 & 396 & ----- & ----- & ---- & ---- & 0.200 & Unique \\
Band7 & ----- & ---- & ---- & 364 & --- & 0.200 & Unique \\
Band8 & ----- & ---- & ---- & ---- & 330 & 0.200 & Unique \\
Band9 & 324 & ---- & ---- & ---- & ---- & 0.200 & Unique \\
Band10 & ----- & ---- & 315 & --- & --- & 0.200 & Unique \\
Band11 & ----- & 294 & ----- & ---- & ---- & 0.200 & Unique \\
Band12 & 270 & ----- & ---- & ---- & ---- & Unique \\
Band13 & ---- & ---- & 260 & ----- & ---- & 0.200 & Unique \\
Band14 & ---- & 255 & ---- & ----- & 0.200 & Unique \\
Band15 & ---- & ----- & ----- & 243 & ---- & 232 & Unique \\
Band16 & --- & --- & --- & 211 & & Monomorphic \\
Band17 & 211 & 211 & 211 & 211 & &
\end{tabular}




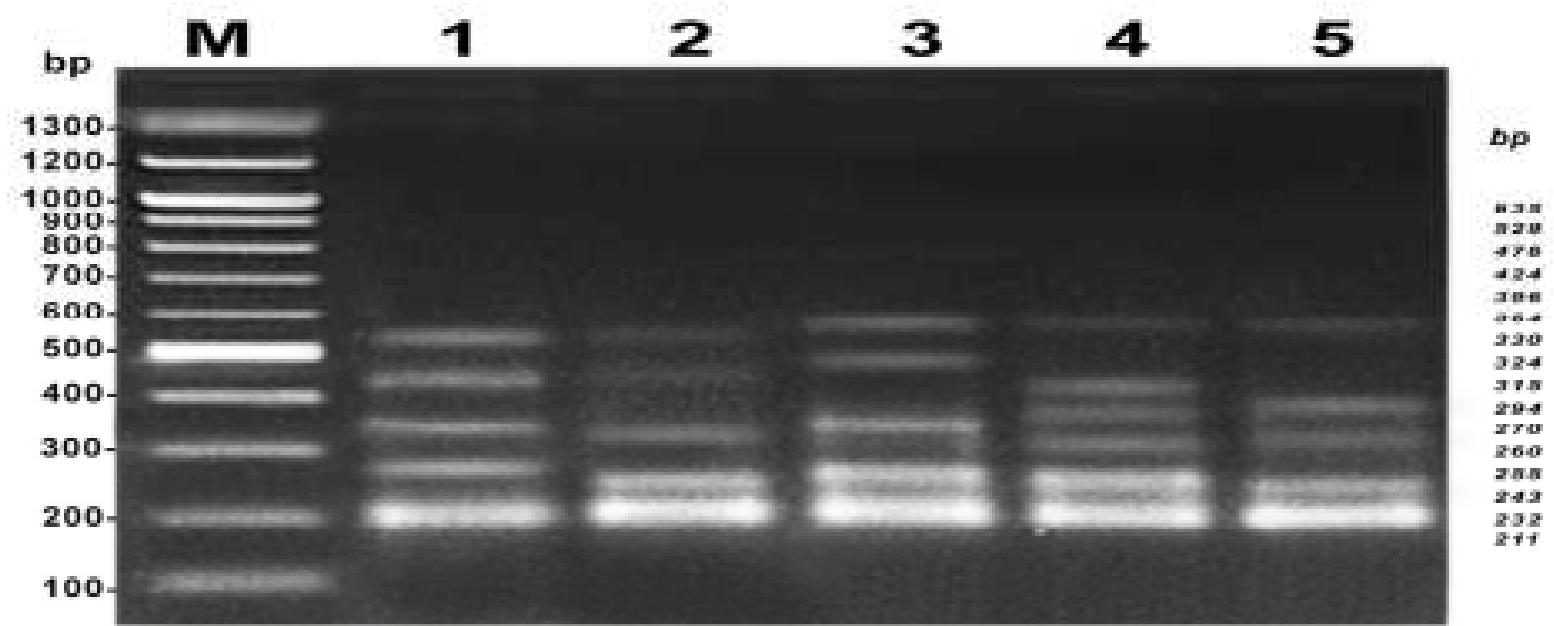

Fig. 3. RAPD-PCR produced for different strain of $P$. gossypilla larvae using primer K15. Where is lane $1=$ Lab, lane 2 = Qalubia, lane 3= Gharbia, lane 4= Menoufia and lane 5= Kafr-Elsheikh.

As summarized in Table (7), the similarity index produced by the primer K15 ranged from 0.18 to 0.40 . The similarity index of the four field colony strains relative to the baseline laboratory strain ranged between 0.18 to 0.22 indicating resistance levels in these field strains.

Table 7. Estimated similarity index between five strains of $P$. gossypiella larvae using primer K15.

\begin{tabular}{|c|c|c|c|c|c|}
\hline Strains & Lab. & Qalubia & Gharbia & Menoufia & $\begin{array}{c}\text { Kafr- } \\
\text { Elsheikh }\end{array}$ \\
\hline Lab. & ---- & 0.22 & 0.18 & 0.22 & 0.22 \\
\hline Qalubia & ----- & ----- & 0.40 & 0.25 & 0.25 \\
\hline Gharbia & ----- & ----- & ----- & 0.20 & 0.40 \\
\hline $\begin{array}{l}\text { Menoufia } \\
\text { Kafr- }\end{array}$ & ----- & ----- & ----- & ----- & 0.25 \\
\hline Elsheikh & ----- & ----- & ----- & ----- & ----- \\
\hline
\end{tabular}

The RAPD-PCR patterns produced by amplification of $P$. gossypiella DNA with primer P8 contained a total of 18 bands (Table, 8 and Fig. 4) These fragments were 4,3,4,3 an4 were appeared in the laboratory strain, Qalubia, Gharbia, Menoufia and Kafr-Elsheikh field colony strain; respectively. The number of DNA fragments ranged from 3-4 bands. Fragments of 555, 433 and $366 \mathrm{pb}$ were shared in laboratory and all field colony strains. One fragment of $611 \mathrm{pb}$ was attained only in the laboratory strain, the fragment of $705 \mathrm{pb}$ was detected only in Gharbia field strain; whereas the fragment of $323 \mathrm{pb}$ was appeared only in Kafr-Elsheikh field strain.

The fingerprints generated by primer $\mathrm{P} 8$ revealed three unique and three monomorphic profiles; respectively.

Table 8. Total numbe and size of RAPD-PCR fragments generated by arbitrary primers in different strains of $P$. gossypiella larvae using primer $P 8$.

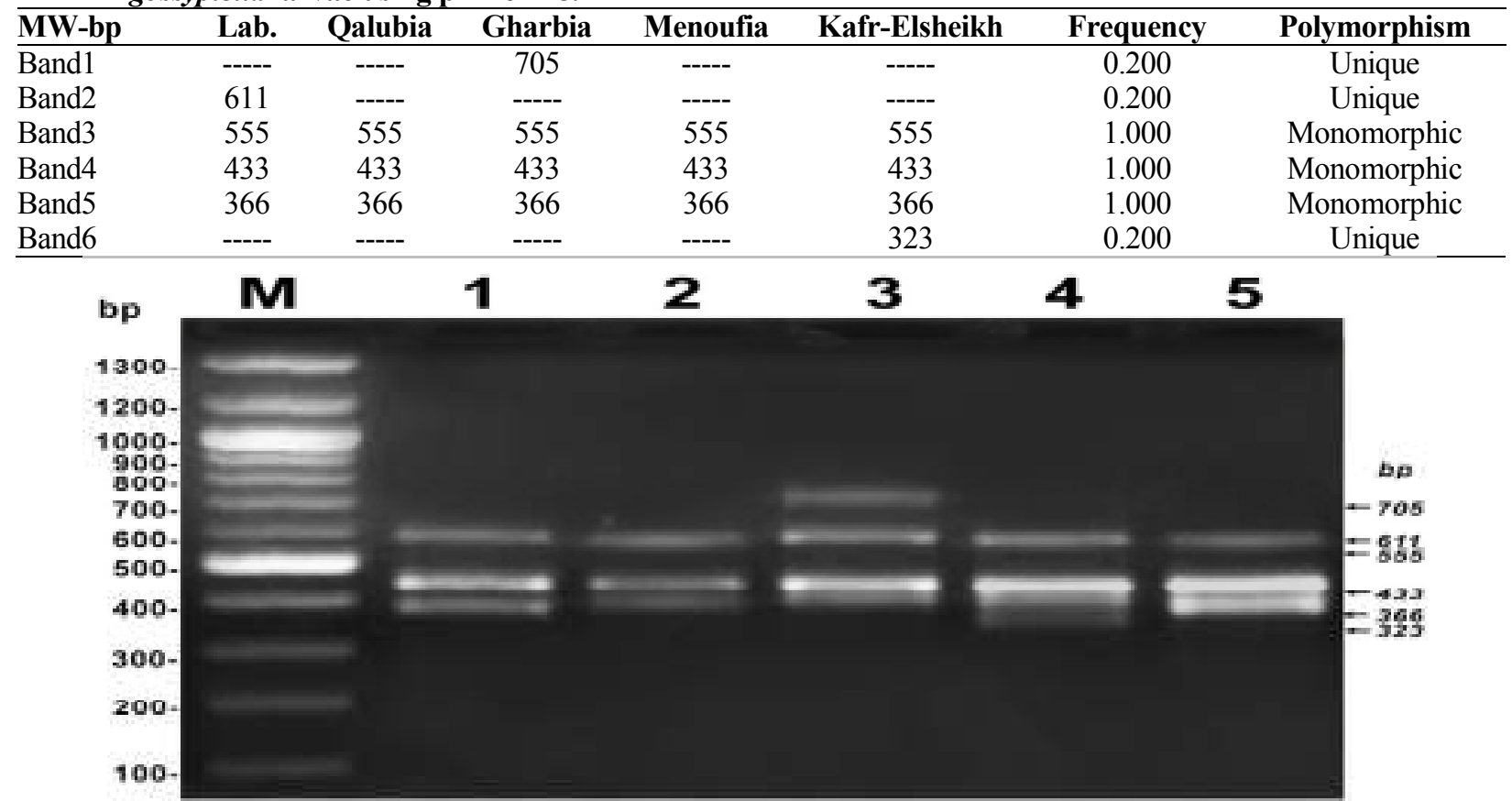

Fig. 4. RAPD-PCR produced for different strain of $P$. gossypilla larvae using primer P8. Where is lane $1=$ Lab, lane 2 = Qalubia, lane 3= Gharbia, lane 4= Menoufia and lane 5= Kafr-Elsheikh. 
As shown in Table (9), the similarity index values were ranged between 0.75 and 0.86 among the five strains under the study.

Table 9. Estimated similarity index between five strains of $P$. gossypiella larvae using primer P8.

\begin{tabular}{lccccc}
\hline Strains & \multicolumn{1}{c}{ Lab. } & Qalubia & Gharbia & Menoufia & $\begin{array}{c}\text { Kafr- } \\
\text { Elsheikh }\end{array}$ \\
\hline Lab. & ----- & 0.86 & 0.75 & 0.75 & 0.86 \\
Qalubia & ----- & ----- & 0.86 & 0.86 & 0.86 \\
Gharbia & ----- & ---- & ----- & 0.75 & 0.86 \\
Menoufia & ----- & ---- & ---- & ---- & 0.86 \\
Kafr- & - & & ---- & ---- & ----- \\
Elsheikh & --- & --- & --- & & \\
\hline
\end{tabular}

Results presented in Table (10) and illustrated in

Fig. (5) revealed that the fingerprints generated by the primer S8 produced 23 number of fragments, these fragments were 4, 6, 5, 4 and 4 fragments associated to laboratory, Qalubia, Gharbia, Menoufia and Kafrel-Sheikh strains; respectively. The fingerprints pattern showed 8 unique and 3 monophormic profiles for the five tested strains in terms in number and position of RAPD fragments. One fragment of $859 \mathrm{pb}$ was detected only in laboratory strain. Three fragments of 999, 895 and $241 \mathrm{pb}$ were appeared only in Qalubia strain. Two fragment of 976 and $696 \mathrm{pb}$ were found only in Gharbia strain. Another one fragment of 239 was detected only in Menoufia field strain, and one fragment of $592 \mathrm{pb}$ was detected only in Kafrel-Sheikh field colony strain. On the other hand, three fragments of 614,425 and $270 \mathrm{pb}$ were shared in the five strains under this study.

Table 10. Total number and size of RAPD-PCR fragments generated by arbitrary primers in different strains of P.gossypiella larvae using primer S8.

\begin{tabular}{lccccccc}
\hline MW-bp & Lab. & Qalubia & Gharbia & Menoufia & Kafr-Elsheikh & Frequency & Polymorphism \\
\hline Band1 & ----- & 999 & ----- & ---- & ---- & 0.200 & Unique \\
Band2 & ----- & ---- & 978 & ---- & --- & 0.200 & Unique \\
Band3 & ---- & 895 & ---- & ---- & --- & 0.200 & Unique \\
Band4 & 859 & ----- & ---- & ---- & ---- & 0.200 & Unique \\
Band5 & ----- & --- & 696 & --- & --- & 0.200 & Unique \\
Band6 & 614 & 614 & 614 & 614 & 614 & 1.000 & Monomorphic \\
Band7 & ----- & ---- & ---- & ---- & 592 & 0.200 & Unique \\
Band8 & 425 & 425 & 425 & 425 & 425 & 1.000 & Monomorphic \\
Band9 & 270 & 270 & 270 & 270 & 270 & 1.000 & Monomorphic \\
Band10 & ----- & 241 & ---- & ---- & ---- & 0.200 & Unique \\
Band11 & ----- & ---- & ---- & 239 & --- & 0.200 & Unique
\end{tabular}

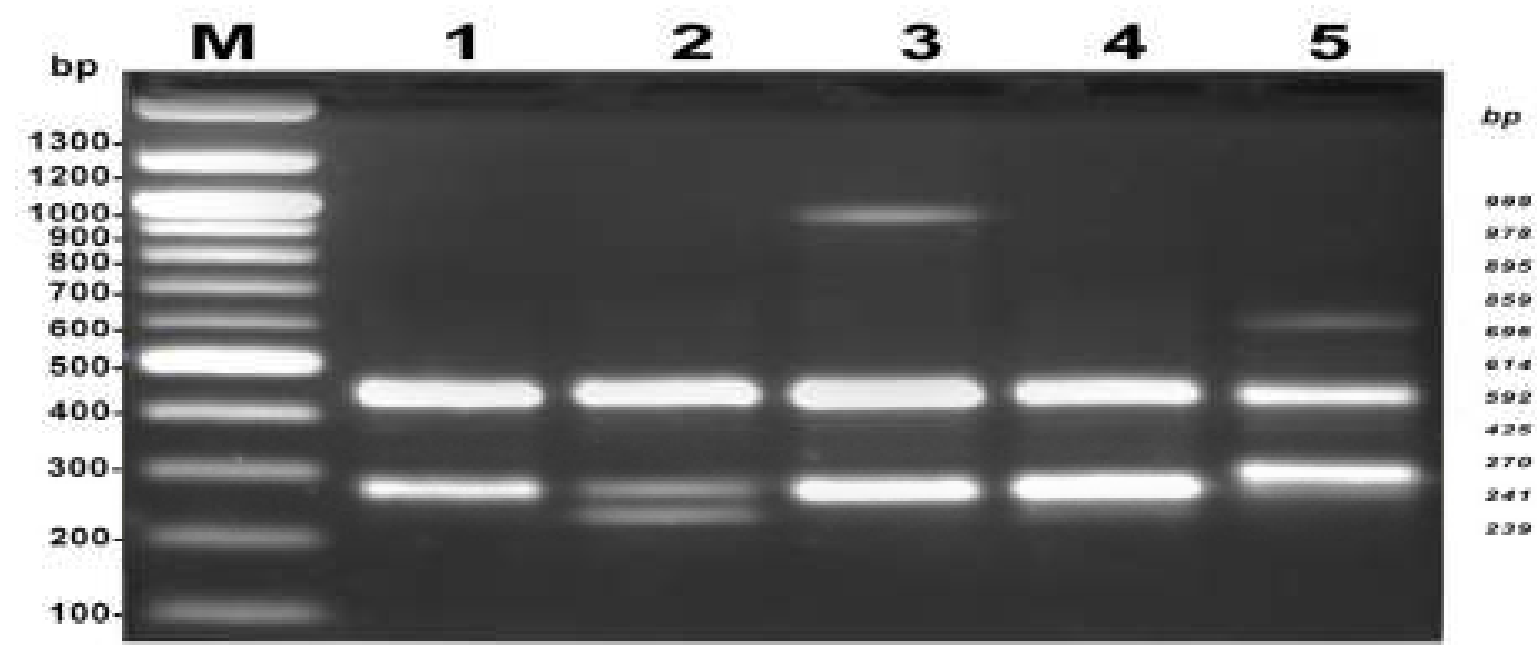

Fig. 5. RAPD-PCR produced for different strain of $P$. gossypilla larvae using primer S8. Where is lane $1=$ Lab, lane 2 = Qalubia, lane 3= Gharbia, lane 4= Menoufia and lane 5= Kafr-Elsheikh.

Results of estimated similarly index between the five strains of $P$. gossypiells using primer S8 are summarized in Table (11). The obtained data revealed that estimated similarity index between the laboratory strain and the four field strains were ranged between 0.60 and 0.75 indicting tolerant strains of the four field colony strains. On the other hand, estimated similarity among the four field colony strains were ranged between 0.54 and 0.75 .
Table 11. Estimated similarity index between five strains of $P$. gossypiella larvae using primer S8.

\begin{tabular}{|c|c|c|c|c|c|}
\hline Strains & Lab. & Qalubia & Gharbia & Menoufia & $\begin{array}{c}\text { Kafr- } \\
\text { Elsheikh }\end{array}$ \\
\hline Lab. & ----- & 0.60 & 0.67 & 0.75 & 0.75 \\
\hline Qalubia & ----- & ----- & 0.54 & 0.60 & 0.60 \\
\hline Gharbia & ----- & ----- & ----- & 0.67 & 0.67 \\
\hline Menoufia & ----- & ----- & ----- & ----- & 0.75 \\
\hline $\begin{array}{l}\text { Kafr- } \\
\text { Elsheikh }\end{array}$ & ----- & ----- & ----- & ------ & ----- \\
\hline
\end{tabular}




\section{J. Plant Prot. and Path., Mansoura Univ., Vol. 10 (1), January, 2019}

Reviewing aforementioned results, it could be revealed that the banding patterns are created using short oligonucleotide primers (10bp in length) of arbitrary sequence in Random Amplified polymorphic DNA (RAPD) technique. These arbitrary sequences are not specific for a particular gene or DNA sequence, so they are designed to screen the whole genome in general detecting any changes between two or more genomes under comparison. These primers bind the homologous sequence along the genome and PCR amplification only occurs when opposing primer sites are about bp apart. Within a population sample, mutation caused by any stress (e.g. insecticide treatment or different temperature) change the base sequence of primer binding sites, allowing polymorphism to be detected (Williams et al., 1990). The word "random" in the term RAPD may be somewhat misleading in that the only random component is the sequence of a primer rather than the region amplified.

RAPD-PCR technique has several advantages over other methods used for studying genetic variability. These advantages can be summarized as: It helps in genetic analysis of any new species without any prior knowledge about the particular DNA sequences for the genes of these new species.

It is not limited to a single locus but theoretically detects polymorphism across the whole genome, either coding or non coding regions in contradiction to biochemical (isozymes and protein) markers which are limited to few genomic regions, so that this method may be used for studying mutations among populations exposed to any mutagen. Different parts of the genome can evolve at different rates (Nei, 1987). Therefore, it is possible that the regions amplified by PCR evolve at higher rate. Thus RAPD-PCR finger prints can obtain a higher variability especially if the amplified regions contain micro or minisatellite DNA (Baruffi et al., 1993).

Because of the small amount of template used in each reaction, this protocol allows for the simultaneous analysis of several primers in a single run. Furthermore, the RAPD-PCR technique does not require the expensive and hazardous use of radioactive nucleotides as in Restriction Fragment Length Polymorphism (RFLP) technique (Cenis and Beitra, 1994). PCR cycling may be initiated overnight and the products are loaded into a gel and analyzed the following day (Chen et al.,1999 and Yoder et al., 1999).

In RAPD finger printing an oligonucleotide primer amplifies distinct DNA fragments. These fragments are referred to as RAPD markers. The number and size of RAPD markers depend on the complementarily of the sequence of a particular primer and template DNA which is characteristic to an individual (Hedrick, 1992 and Williams et al., 1993).

In the present work it was found that DNA of a good quality is a prerequisite to have reproducible results from RAPD-PCR technique. The highest numbers of amplified fragments were 25 resulted from primer C7, whereas the lowest number of amplified fragments were 14 resulted from primer $\mathrm{C} 2$ in $P$. gossypiell larvae.

Primers usually do not have the same amplification efficiency. Kantanen et al. (1995) found that some primers fail to amplify; others produce too complex banding patterns. In the present investigation, the genomic DNA of the laboratory strain and field colony strains was screened for DNA damage or sequences changes using five primers of arbitrary sequences. The absence of a fragment from the RAPD pattern of tested insects may be due to changes in DNA sequence of the insect under investigation. The effect of deletion, insertion or breakage at one or both primer annealing sites on a greater distance than can be amplified (Rafalski et al.1991). RAPD-PCR produced a series of discrete DNA fragments, which typically vary in intensity and range in size from 77-2505 bp (Abdel-Baset, 2009).

The RAPD patterns resulted from amplification of DNA of laboratory \& field colony strains of $P$. gossypiella revealed the lowest value of similarity index $(0.0)$ which reflects the highest degree of change in DNA structure and sequence was recorded between the genomes of the different strains using primer E7. The same findings were reported by Soliman (1997) who found that primers OPA1,2 and 3 exhibited a degree of differences that reached 66.71 to $100 \%$ between the genomic DNA untreated and treated med flies. The present results are accordance with those obtained by Abdel-Baset (2009). She revealed that primers OPA-13, OPA-15 and OPD-5 are strong tools to investigate changes in the $P$. gossypiella and Culex pipiens genomic DNA, probably due to changes in sequences of these primers. The sequence of the primer is known to be the factor for screening DNA or polymorphism. The present study are going in line with those of Lakshmi (2012) who revealed that the $5^{\text {th }}$ instar larvae of silk worm, Anthereae mylitta exposed to low temperatures during winter have shown significant variation in the levels of various bimolecular to cope with heat-chock. The obtained results are supported with those published by Abdel-Salam et al. (2013). They recorded that the RAPD patterns resulted from amplification of DNA of the field colony strains and laboratory strain of the pink bollworm, $P$. gossypiella fourth instar larvae revealed that the lowest value of similarity index (0.00), which reflects the highest degree of change in DNA structure and sequence between the genomes of untreated pink bollworm larvae and those exposed to a wide spread of different insecticides which used for controlling the pest. The results are in agreement with those reported by Salem (2018)., who demonstrated that the RAPD patterns resulted from amplification of DNA structure and sequence were different between the genomes of untreated pink bollworm and those exposed to a wide spread of different insecticides used to control the pest in the field. The primer BO3 recorded similarity index1.0 between the laboratory strain and the field strain with Trichogramma evanescens. The less damaging effect of insecticides on the pink bollworm DNA could be attributed to a good detoxifying mechanism developed by the insect as a result of wide spread and long term exposure of insect larvae in additional to different thermal degrees in the fields.

\section{REFERENCES}

Abdel-Baset, T. T. (2009): Comparative toxicological and molecular studies on the pink bollworm, Pectinophora gossypiella and the mosquito, Culex pipiens. Ph. D. Thesis, Fac. Sci., Ain-Shams Univ. 
Abd El-Hafez, A.; A. G. Metwally and M. R. A. Saleh (1982): Rearing pink bollworm Pectinophora gossypiella (Saunders) on kidney bean diet in Egypt (Lepidoptera: Glechiidae). Res. Bull., Fac. Agric., Zagazig Univ., 7 (5): 10pp.

Abdel- Salam, D. A., S. A. El- Rafai, A. A. Khidr and G. B. El-Saadany (2013): Use of RAPD technique to study genetic variation of field colony collected pink bollworm, Pectinophora gossypiella (Saunders). Egypt. J. of Appl. Sci., 28(5): 76-93.

Baruffi, L.; G. Damiani; C. R. Gugliclmino; C. Bandis; A. R. Malacrida; J. L. Cenis; P. Perez and A. Fereess (1993): Identification of Aphid (Homoptera : Aphididae) species and Entomol. Soc. Am., 86(5): 545-550.

Cenis, J. L. And F. Beitia (1994): Application de la technica RAPD-PCR and polimorfica insects. Invet. Agr. : Prod. Prot. Veg., 9(2): 289-297.

Chen, X.; Romine, C.P.; Tan,Q.; Schlagnhaufer, B.; Ospina, G.M.D. ; Royes, D.J. and Huff, D.R. (1999):PCR-based genotyping of epidemic and preepidemic Trichoderma isolates associated with green mold of Agricus bisporus.Apple.Envir . Microbial. , 65:2674-2678.

Hedrick, P.(1992): Shooting the RAPDs. Nature, 355:679680.

Kantanen, J.; Vikki, J.; Elo, and Maki, T.A. (1995):Random amplified polymorphis DNA in cattle and sheep. Application for detecting genetic variation. A NIMA .GENET, 26:315-320.

Lakshmi, V. (2012): Studies on biochemical components of the larval haemolemph, fat body and silk gland of trophical tasar silkworm, Anthereae mylitta Drury (Dada T. V.). European J. of Experimental Biology, 2(6): 2238-2242.
Nei, M. (1987): Molecular evolutionary genetics .Colombia Univ., Press New York. PhD. thesis, Dept. Entomol., Fac. Sci., Ain shames Univ., Cairo, Egypt.

Rafalski, J.A.; Tingey, S.V and Williams, J.G.K. (1991): Markers a new technology for genetic mapping and plant breeding. Ag. Biotich. News and Inform., 3(4):645-648.

Salem, Manal M. I. (2018): Toxicological and molecular comparative studies on the pink bollworm, Pectinophora gosssypiella (Saunders). PhD. Thesis, Faculty of Agric., Benha univ.

Soliman, A.A.I. (1997): New approaches in the MED fly, Ceratitis capittata control and research using sterile insect technique .Ph.D. Thesis ,Dept. Entomol., Fac. Sci., Ain shames Univ., Cairo, Egypt.

Willcooks, F. C. (1916): The insects and related pest of Egypt. VI. The insect and related pests injuries to the cotton plant. Pt. i. The pink bollworrm Sultanic. Agric.

Williams, J.G.K.; Hanafey, M.K.; Rafalski, J.A. and Tingey, S.V. (1993): Genetic analysis using random amplified polymorphic DNA marker. Methods Enzymol 218:704-740.

Williams, J.G.K.; Kubellick, A.R; Lirak, K.J.; Rafalski, J.A. and Tingey, S.V. (1990): DNA polymorphism amplified by arbitrary primers as useful as genetic markers. Nucleic Acid Reserch, 18(22):6531- 6535.

Yoder, S., Argyeta, A. ; Aronson,T.; Berlin, O.G.W.; Tomasck, P.Gloven, N.; Froman, S. and Stolma,G. (1999):PCR comparison of Mycobacterium avium isolates obtained from patients and foods. App. Environ. Microbial, $65: 2650$ - 2653

\section{دراسات على الاختلافات الجينية بين السلالات الحقلية لدودة اللوز القرنفلية باستخدام وسيلة البلمرة المتسلسلة

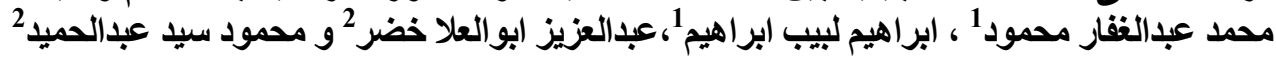

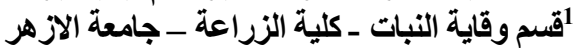 2معه بحوث وقاية النباتات ـ مركز البحوث الزراعية ـ الاقى ـ الجيزة}

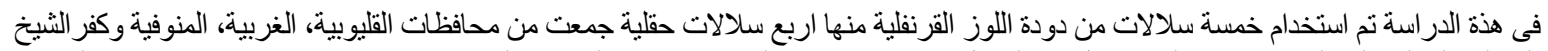

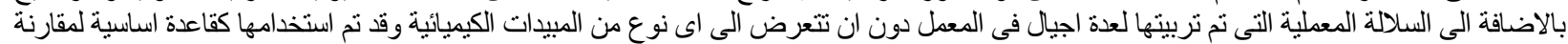

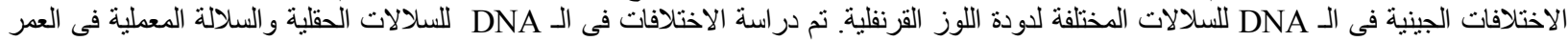

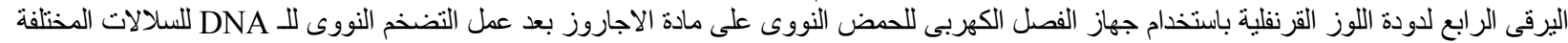

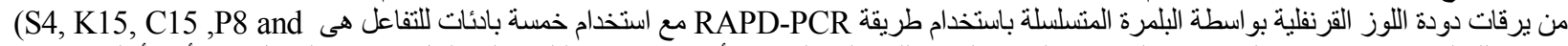

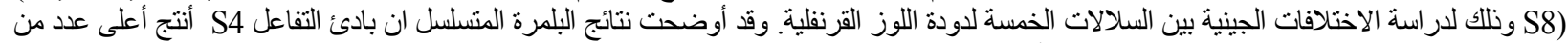

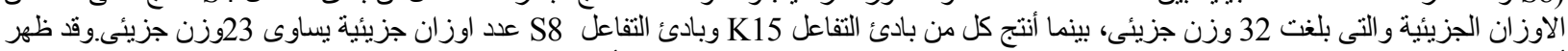

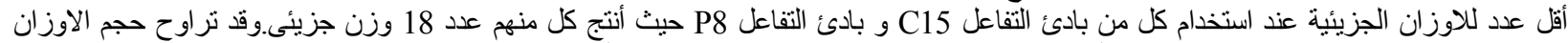

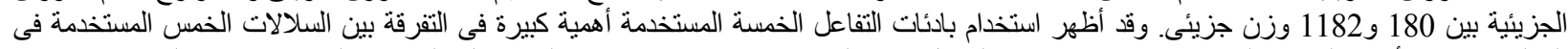

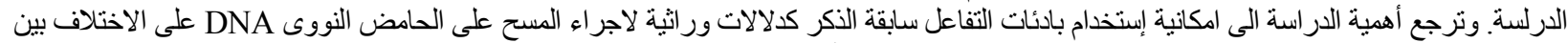

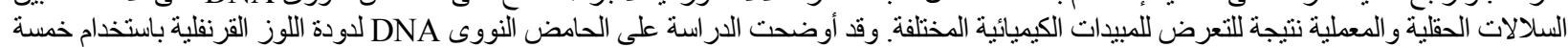

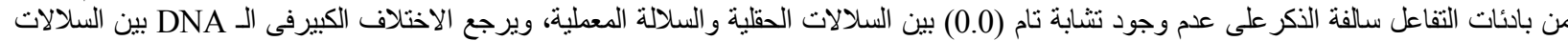

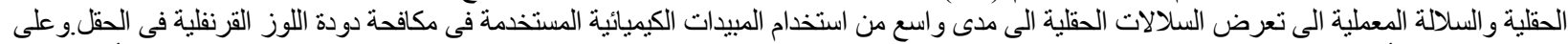

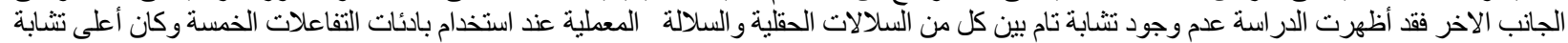

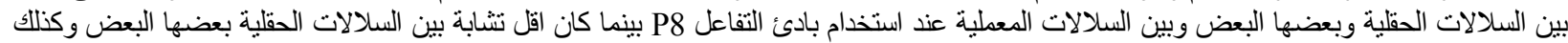

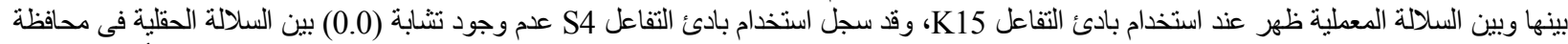

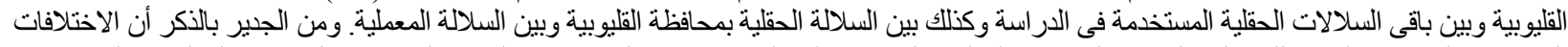

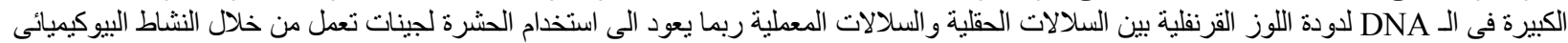
على از الة سمية المبيدات الكيميائية التى تستخدم على نطاق واسع فى مكافحة السلالات الحقلية لدودة اللوز القرنفية التلية فى الحقل. 